\title{
Heteroplasmy for the Cytochrome $b$ Gene in Podosphaera xanthii and its Role in Resistance to Qol Fungicides in Spain
}

\author{
Alejandra Vielba-Fernández, Davinia Bellón-Gómez, and Juan A. Torés, Instituto de Hortofruticultura Subtropical y Mediterránea "La \\ Mayora", Universidad de Málaga - Consejo Superior de Investigaciones Científicas (IHSM-UMA-CSIC), Estación Experimental "La Mayora", \\ 29750 Algarrobo-Costa (Málaga), Spain; Antonio de Vicente, Alejandro Pérez-García, and Dolores Fernández-Ortuño, ${ }^{\dagger}$ IHSM-
} UMA-CSIC, Departamento de Microbiología, Facultad de Ciencias, Universidad de Málaga, 29071 Málaga, Spain

\begin{abstract}
In Spain, management of the cucurbit powdery mildew pathogen Podosphaera xanthii is strongly dependent on chemicals such as quinone outside inhibitor (QoI) fungicides. In a previous report, widespread resistance to QoI fungicides in populations of $P$. xanthii in south-central Spain was documented, but the molecular mechanisms of resistance remained unclear. In this work, the role of the Rieske$\mathrm{FeS}($ risp) and the cytochrome $b(c y t b)$ gene mutations in QoI resistance of $P$. xanthii were examined. No point mutations in the risp gene were found in the three QoI-resistant isolates analyzed. For $c y t b$, sequence analysis revealed the presence of a G143A substitution that occurs in many QoI-resistant fungi. This mutation was always detected in QoI-

resistant isolates of $P$.xanthii; however, it was also detected in sensitive isolates. To better understand the role of heteroplasmy for $c y t b$ in QoI resistance of $P$. xanthii, an allele-specific quantitative PCR was developed to quantify the relative abundance of the G143 (sensitive) and A143 (resistant) alleles. High relative abundance of A143 allele (70\%) was associated with isolates resistant to QoI fungicides; however, QoIsensitive isolates also carried the mutated allele in frequencies ranged from 10 to $60 \%$. Our data suggest that G143A mutation in $c y t b$ is the primary factor involved in QoI resistance of $P$. xanthii but the proportion of G143 and A143 alleles in an isolate may determine its QoI resistance level.
\end{abstract}

Cucurbit powdery mildew caused by Podosphaera xanthii (Castagne) U. Braun \& N. Shishkoff is a devastating disease worldwide and one of the most important diseases affecting these crops (Pérez-García et al. 2009). Fungicide application and the use of resistant cultivars are the main strategies for disease control (McGrath 2001) to prevent further spread of the pathogen, dissemination of the disease, and consequent yield and economic losses. Unfortunately, the intense use of chemicals often results in the development of resistance, reducing the efficacy of chemical control. The rapid development of fungicide resistance by $P$. xanthii is a major problem, and resistance to multiple classes of fungicides including methyl benzimidazole carbamates, sterol demethylation inhibitors, morpholines, organophosphates, hydroxypyrimidines, quinoxalines, and quinone outside inhibitors (QoIs) has been well documented in many areas of the world (Bellón-Gómez et al. 2015; Fernández-Ortuño et al. 2006; Ishii et al. 2001; López-Ruiz et al. 2010; McGrath 2001; Sedláková and Lebeda 2008).

QoI fungicides are important for the control of a wide range of plant pathogenic fungi and oomycetes (Bartlett et al. 2002); they are currently the second most widely used class of agricultural fungicides with annual sales exceeding $\$ 2.7$ billion (Xiao et al. 2014). In Spain, as in other parts of the world, cucurbit growers who began using QoIs extensively reported control failures of powdery mildew by these fungicides soon after their registration in 1997. Field resistance to QoI fungicides was first reported in wheat powdery mildew in northern Germany in 1998 (Anonymous 1998). In Japan, a rapid decline in QoI fungicide efficacy against cucumber powdery mildew

${ }^{\dagger}$ Corresponding author: D. Fernández-Ortuño;

E-mail: dfernandez-ortuno@uma.es

Funding: This study was supported by grants from the former "Ministerio de Ciencia e Innovación (MICINN)" (AGL2010-21848-CO2-01/AGR) and current "Ministerio de Economía y Competitividad (MINECO)" (AGL201341939-R), both co-financed by FEDER funds (European Union).

Accepted for publication 26 February 2018.

C) 2018 The American Phytopathological Society was reported between late 1998 and early 1999 (Ishii et al. 2001). Widespread resistance to QoI fungicides in populations of $P$. xanthii in south-central Spain was first detected in 2002 (Fernández-Ortuño et al. 2006).

The fungicidal activity of QoI fungicides relies on their ability to inhibit mitochondrial respiration by binding at the ubiquinol oxidation site (Qo) of the cytochrome $b c_{1}$ complex, which involves the cytochrome $b$ (Cytb) and the mobile extrinsic domain of the Rieske-FeS protein (Risp), and it is located in the inner mitochondrial membrane of fungi (Gisi et al. 2002). QoI fungicides block the transfer of electrons to cytochrome $c_{l}$, leading to an energy deficiency in fungal cells by halting the production of ATP and ultimately to fungal death (Anke 1995; Fernández-Ortuño et al. 2008a). QoIs are considered by the Fungicide Resistance Action Committee to have a high risk for resistance development (www. frac.info).

Although several molecular mechanisms are associated with QoI insensitivity, the primary one involves point mutations in the target site of QoI fungicides, resulting in peptide sequence changes that prevent fungicide binding (Fernández-Ortuño et al. 2008a). Three amino acid substitutions: from phenylalanine to leucine at position 129 (F129L), from glycine to arginine at position 137 (G137R), and from glycine to alanine at position 143 (G143A), have been detected in Cytb of several phytopathogenic fungi and oomycetes that are resistant to QoIs (Fernández-Ortuño et al. 2008a; Gisi et al. 2002). In most cases, isolates expressing the G143A mutant protein exhibit high levels of resistance and failure of QoI disease control, whereas isolates with F129L or G137R exhibit moderate resistance (Sierotzki et al. 2000). Other publications have also hypothesized that a structural change in the Risp protein could be the mechanism responsible for resistance to QoI fungicides in some basidiomycetes (Brand et al. 1993) and ascomycetes (Fernández-Ortuño et al. 2008b; Walker et al. 2009).

In $P$. xanthii, the role of the G143A mutation in QoI resistance remains controversial. In a preliminary study with isolates from Japan, the mutation was found in two out of three QoI-resistant isolates analyzed (Ishii et al. 2001); by contrast, in a study with isolates from south-central Spain, the mutation was never observed in resistant isolates (Fernández-Ortuño et al. 2008b). The purpose of this study was to elucidate the molecular basis of resistance to QoI fungicides in P. xanthii in Spain. The hypothesis that a 
structural change in the Qo pocket is responsible for QoI resistance was reexamined.

\section{Materials and Methods}

$P$. xanthii isolates, plant material, and culture conditions. The 22 monoconidial isolates of $P$. xanthii used in this work were obtained and characterized in a previous study (Fernández-Ortuño et al. 2006; Table 1). The isolates were kept at $-80^{\circ} \mathrm{C}$ until use as previously described (Pérez-García et al. 2006). For conidia production, all isolates were cultured on cv. Negro Belleza zucchini (Cucurbita pepo L.; Semillas Fitó) and maintained in vitro as previously described (Álvarez and Torés 1997).

In vitro fungicide sensitivity assay. A leaf-disc bioassay was used to determine the QoI sensitivity phenotypes of $P$. xanthii isolates. A commercial formulation of the QoI fungicide kresoximmethyl (Stroby, BASF) was used. The conditions and methods necessary to carry out the fungicide sensitivity test were previously reported (Fernández-Ortuño et al. 2006). Briefly, leaf discs obtained from cotyledons of 8-day-old zucchini plants were placed adaxial side down into 9-cm-diameter Petri dishes containing sterile filter paper imbibed with $3 \mathrm{ml}$ of fungicide solution. Tests were performed with final concentrations of $1,2.5,5,25,50,250$, and $500 \mu \mathrm{g} / \mathrm{ml}$ of kresoxim-methyl. Untreated control discs were imbibed with $3 \mathrm{ml}$ of sterile water. After $24 \mathrm{~h}$, the discs were placed onto agar medium ( $40 \mathrm{~g}$ sucrose, $30 \mathrm{mg}$ benzimidazole, $10 \mathrm{~g}$ agar, 1 liter distilled water) and inoculated on their adaxial side with conidia of the selected $P$. xanthii isolate using a soft paintbrush. After 8 days of incubation, powdery mildew symptoms were recorded according to a 0 to 3 scale of values; 0 , absence of visible symptoms; $1,<25 \%$ of disc surface covered by powdery mildew; 2,25 to $50 \%$; and $3,>50 \%$ of disc surface covered by powdery mildew. Fungicide concentrations inhibiting $50 \%$ of growth $\left(\mathrm{EC}_{50}\right)$ were graphically determined from log-transformation of percentages of inhibition and regression against the natural logarithm of fungicide concentrations as previously described (Fernández-Ortuño et al. 2006). Experiments were replicated three times.

DNA extraction, amplification, and sequencing of the risp and cytb genes. For total DNA isolation, biomass of $P$. xanthii isolates composed of conidia and hypha was carefully harvested with a spatula from 10-day-old powdery mildew-infected zucchini cotyledons. Total DNA was extracted using the DNeasy Plant Mini Kit (Qiagen GmbH) following the manufacturer's recommendations for DNA purification from fungal tissues. Fragments of 1,009 and $323 \mathrm{bp}$ of the coding sequence encompassing amino acid codons 1-232 and 51-157 of the $P$. xanthii risp and $c y t b$ genes, respectively, were amplified using primers 66-Rieske-F (5'-CCAGTGCACACAGGTTTCAC-3')/955Rieske-R (5'-CACGACGTGGCCAGACTATT-3') and F3cytb-Px (5'-AGCAATGCATTACAACCCTAGC-3')/R3cytb-Px (5'-CTATT CATGGTATAGCGCTC- $\left.3^{\prime}\right)$. These primers were designed with the program Geneious 10.2.2 (Kearse et al. 2012) based on sequence data, contigs c364 and c24909, obtained from the epiphytic and haustorial transcriptome of $P$. xanthii (Seoane et al., unpublished data). PCR was carried out in a PTC-200 DNA engine cycler (Bio-Rad Laboratories Inc.). For the risp gene amplification, a final volume of $25 \mu \mathrm{l}$ containing $0.2 \mathrm{U}$ of Phusion High-Fidelity DNA Polymerase (Thermo Fisher Scientific), $5 \mu$ l of $5 \times$ Phusion HF Buffer, $0.2 \mathrm{mM}$ each dNTP, $0.2 \mu \mathrm{M}$ of each primer, and $20 \mathrm{ng}$ of fungal template DNA; and the following PCR conditions: $2 \mathrm{~min}$ at $92^{\circ} \mathrm{C}$; followed by 30 cycles of $92^{\circ} \mathrm{C}$ for $30 \mathrm{~s}, 60.4^{\circ} \mathrm{C}$ for $30 \mathrm{~s}$, and $72^{\circ} \mathrm{C}$ for $54 \mathrm{~s}$; with a final elongation at $72^{\circ} \mathrm{C}$ for $10 \mathrm{~min}$ were used. For $c y t b$, PCR was performed in a reaction mixtures $(50 \mu \mathrm{l})$ containing $1.25 \mathrm{U}$ of GoTaq G2 Flexi DNA Polymerase (Promega), $10 \mu \mathrm{l}$ Green GoTaq Flexi Buffer, $0.2 \mathrm{mM}$ each dNTP, $0.2 \mu \mathrm{M}$ of each primer, $3 \mathrm{mM} \mathrm{MgCl}_{2}$, and $20 \mathrm{ng}$ of fungal genomic DNA. PCR amplification were achieved following an initial preheating of $2 \mathrm{~min}$ at $95^{\circ} \mathrm{C}$; followed by 35 cycles consisting of $30 \mathrm{~s}$ denaturation at $95^{\circ} \mathrm{C}, 30 \mathrm{~s}$ of annealing at $51.5^{\circ} \mathrm{C}$, and $30 \mathrm{~s}$ of extension at $72^{\circ} \mathrm{C}$; and a final extension stage of $10 \mathrm{~min}$ at $72^{\circ} \mathrm{C}$.

PCR products were separated in ethidium-bromide-stained $1 \%(\mathrm{w} / \mathrm{v})$ agarose gels, run in $1 \times$ Tris-Borate-EDTA buffer, and exposed to UV light to visualize the DNA fragments. PCR products were purified using the ExoSAP-IT PCR Purification Kit (USB Corporation) following the manufacturer's instructions and sequenced in both directions at Macrogen-Europe (Amsterdam). Nucleotide sequences were analyzed, assembled, and aligned with DNASTAR sequence analysis software (DNASTAR, Inc.).

To explore putative mitochondrial heteroplasmy in $P$. xanthii for cytb by PCR, amplifications were performed using DNA from 10 QoI-sensitive and 12 -resistant isolates. The PCR products selected

Table 1. In vitro QoI sensitivity, origin, effective inhibitory concentrations $\left(\mathrm{EC}_{50} ; \mu \mathrm{g} / \mathrm{ml}\right)$ to the QoI fungicide kresoxim-methyl, and molecular detection of the G143A mutation in Podosphaera xanthii isolates

\begin{tabular}{|c|c|c|c|c|c|c|}
\hline Isolate & Year & Location & Host & $\mathbf{E C}_{50}$ & Genotype of $c y t b^{\mathbf{a}}$ & GenBank accession no. \\
\hline \multicolumn{7}{|l|}{$\overline{\text { QoI-sensitive }}$} \\
\hline UMAFSf8 & 1988 & Málaga & Melon & 0.6 & G143 & MG712569 \\
\hline UMAFSf30 & 1993 & Málaga & Zucchini & 8.0 & G143 & MG712570 \\
\hline UMAFSf45 & 1996 & Almería & Melon & 0.8 & G143 & MG712571 \\
\hline UMAFSf61 & 1999 & Greece & Cucumber & 2.5 & G143 & MG712572 \\
\hline UMAF2201 & 2002 & Almería & Zucchini & 3.0 & A143 & MG712574 \\
\hline UMAF2208 & 2002 & Almería & Zucchini & 2.0 & G143 & MG712575 \\
\hline UMAF2240 & 2002 & Almería & Zucchini & 0.7 & G143 & KJ004066 \\
\hline UMAF22770 & 2004 & Almería & Zucchini & 0.8 & G143 & KJ004065 \\
\hline UMAF24732 & 2004 & Almería & Watermelon & 1.0 & A143 & KJ004045 \\
\hline UMAF81960 & 2004 & Badajoz & Melon & 1.4 & A143 & MG712578 \\
\hline \multicolumn{7}{|l|}{ QoI-resistant } \\
\hline UMAFSf202 & 1999 & Málaga & Melon & $>500$ & A143 & MG712573 \\
\hline UMAF2355 & 2002 & Almería & Cucumber & $>500$ & A143 & KJ004059 \\
\hline UMAF3180 & 2002 & Murcia & Melon & $>500$ & A143 & KJ004071 \\
\hline UMAF3190 & 2002 & Murcia & Melon & $>500$ & A143 & KJ004049 \\
\hline UMAF31443 & 2003 & Murcia & Melon & $>500$ & G143 & KJ004064 \\
\hline UMAF31464 & 2003 & Murcia & Melon & $>500$ & A143 & KJ004048 \\
\hline UMAF31846 & 2004 & Murcia & Melon & $>500$ & A143 & MG712576 \\
\hline UMAF45631 & 2003 & Valencia & Pumpkin & $>500$ & A143 & KJ004057 \\
\hline UMAF61140 & 2002 & Córdoba & Melon & $>500$ & A143 & KJ004058 \\
\hline UMAF61164 & 2002 & Córdoba & Melon & $>500$ & A143 & MG712577 \\
\hline UMAF71620 & 2003 & Ciudad Real & Melon & $>500$ & A143 & KJ004078 \\
\hline UMAF72174 & 2002 & Ciudad Real & Zucchini & $>500$ & G143 & KJ004050 \\
\hline
\end{tabular}

${ }^{\text {a }}$ Genotype of the $c y t b$ gene at codon 143 was determined by PCR and sequencing. 
were ligated directly into the pCR 4-TOPO Vector (Thermo Fisher Scientific) using the TOPO TA Cloning Kit for Sequencing Vector (Thermo Fisher Scientific). Ligation mixtures were transformed into One Shot TOP10 Chemically Competent Escherichia coli (Thermo Fisher Scientific) using the chemical transformation procedure described by the manufacture. Plasmid DNA was extracted from sensitive and resistant colonies with the GenElute Plasmid Miniprep Kit (Sigma-Aldrich). Ten clones were then sequenced and analyzed for each isolate as described above to characterized $c y t b$ alleles.

Allele-specific ARMS assay. In order to detect and quantify $c y t b$ alleles containing the G143A mutation in the mitochondrial DNA of $P$. xanthii, a real-time amplification refractory mutation system PCR (ARMS qPCR) was developed. The amplification refractory mutation system (ARMS) is an amplification strategy in which PCR primers are designed to discriminate among templates that differ by a single nucleotide residue. Primers are used to preferentially amplify one allele by matching the desired allele and mismatching the other allele at the 3' end of the primer (Bai and Wong 2004; Wang et al. 2011). For the specific amplification of the G143 and A143 cytb alleles, the reverse primers ARMS-cytbS (5'-GCGCTCATAAGGT TAGTAATAACGGTTGCGC-3') and ARMS-cytbR (5'-GCGCTCA TAAGGTTAGTAATAACGGTTGCGG-3') were used, respectively. These primers were used in combination with the common forward primer F3cytb-Px described previously. The specificity of the primers were first checked in PCR performed in a final volume of $50 \mu \mathrm{l}$ containing $20 \mathrm{ng}$ of G143 and A143 cytb alleles cloned on plasmid DNA, $0.2 \mu \mathrm{M}$ of each primer, $0.2 \mathrm{mM}$ of each dNTP, $3 \mathrm{mM} \mathrm{MgCl}_{2}, 10 \mu \mathrm{l}$ Green GoTaq Flexi Buffer, and $0.5 \mathrm{U}$ of GoTaq G2 Flexi DNA Polymerase (Promega Corporation). PCR was conducted with an initial preheating for $5 \mathrm{~min}$ at $94^{\circ} \mathrm{C}$; followed by 25 cycles $94^{\circ} \mathrm{C}$ for $1 \mathrm{~min}, 70^{\circ} \mathrm{C}$ for $1 \mathrm{~min}$, and $72^{\circ} \mathrm{C}$ for $25 \mathrm{~s}$; with a final elongation at $72^{\circ} \mathrm{C}$ for $10 \mathrm{~min}$. The PCR products were separated as described previously.

Quantitative ARMS qPCR was performed in a DNA Engine Opticon 2 Continuous Fluorescence Detector System (MJ Research). Each reaction was prepared in a total volume of $10 \mu \mathrm{l}$ containing $5 \mathrm{ng}$ of fungal template DNA, $0.4 \mu \mathrm{M}$ of each primer, and $5 \mu \mathrm{l}$ of SsoFast EvaGreen Supermix (Bio-Rad Laboratories Inc.). The cycling conditions were as follows: $30 \mathrm{~s}$ at $95^{\circ} \mathrm{C}$ followed by 40 cycles of $95^{\circ} \mathrm{C}$ for $5 \mathrm{~s}, 5 \mathrm{~s}$ at $70^{\circ} \mathrm{C}$. This cycle was followed by a melting curve analysis, ranging from 65 to $95^{\circ} \mathrm{C}$, with temperature increasing in steps of $0.5^{\circ} \mathrm{C}$ every $5 \mathrm{~s}$. Data were analyzed with the Opticon Monitor analysis software version 2.02.24 (MJ Research), and the relative abundance of each allele was finally determined. Means and standard deviations were calculated from at least three biological replicates. Three replicates of the PCR were used for each biological replicate.

\section{Results}

Sensitivity of $P$. xanthii isolates to kresoxim-methyl. To confirm the QoI resistance phenotypes of the 22 P. xanthii isolates used in this study, a mycelial growth was assessed on leaf discs treated

Table 2. Analysis of $c y t b$ heteroplasmy in QoI-sensitive and -resistant Podosphaera xanthii isolates by ligating PCR fragments into cloning plasmids. Ten clones were analyzed per isolate. Nucleotide sequences at codon 143 and the frequencies (\%) of sensitive (G143) and resistant (A143) cytb alleles are given

\begin{tabular}{|c|c|c|c|}
\hline \multirow[b]{2}{*}{ Isolate } & \multicolumn{2}{|c|}{ Codon 143} & \multirow{2}{*}{$\begin{array}{l}\text { Frequency of sensitive/ } \\
\text { resistant alleles }\end{array}$} \\
\hline & GGT (Gly) ${ }^{a}$ & $\overline{\text { GCT (Ala) }}{ }^{\mathrm{a}}$ & \\
\hline \multicolumn{4}{|l|}{ QoI-sensitive } \\
\hline UMAFSf8 & 5 & 5 & $50 / 50$ \\
\hline UMAFSf30 & 6 & 4 & $60 / 40$ \\
\hline UMAFSf45 & 4 & 6 & $40 / 60$ \\
\hline UMAFSf61 & 5 & 5 & $50 / 50$ \\
\hline UMAF2201 & 4 & 6 & $40 / 60$ \\
\hline UMAF2208 & 4 & 6 & $40 / 60$ \\
\hline UMAF2240 & 9 & 1 & $90 / 10$ \\
\hline UMAF22770 & 8 & 2 & $80 / 20$ \\
\hline UMAF24732 & 4 & 6 & $40 / 60$ \\
\hline UMAF81960 & 4 & 6 & $40 / 60$ \\
\hline \multicolumn{4}{|l|}{ QoI-resistant } \\
\hline UMAFSf202 & 0 & 10 & $0 / 100$ \\
\hline UMAF2355 & 1 & 9 & $10 / 90$ \\
\hline UMAF3180 & 0 & 10 & $0 / 100$ \\
\hline UMAF3190 & 2 & 8 & $20 / 80$ \\
\hline UMAF31443 & 2 & 8 & $20 / 80$ \\
\hline UMAF31464 & 2 & 8 & $20 / 80$ \\
\hline UMAF31846 & 0 & 10 & $0 / 100$ \\
\hline UMAF45631 & 3 & 7 & $30 / 70$ \\
\hline UMAF61140 & 1 & 9 & $10 / 90$ \\
\hline UMAF61164 & 0 & 10 & $0 / 100$ \\
\hline UMAF71620 & 1 & 9 & $10 / 90$ \\
\hline UMAF72174 & 1 & 9 & $10 / 90$ \\
\hline
\end{tabular}

${ }^{a}$ Glycine (Gly); Alanine (Ala).

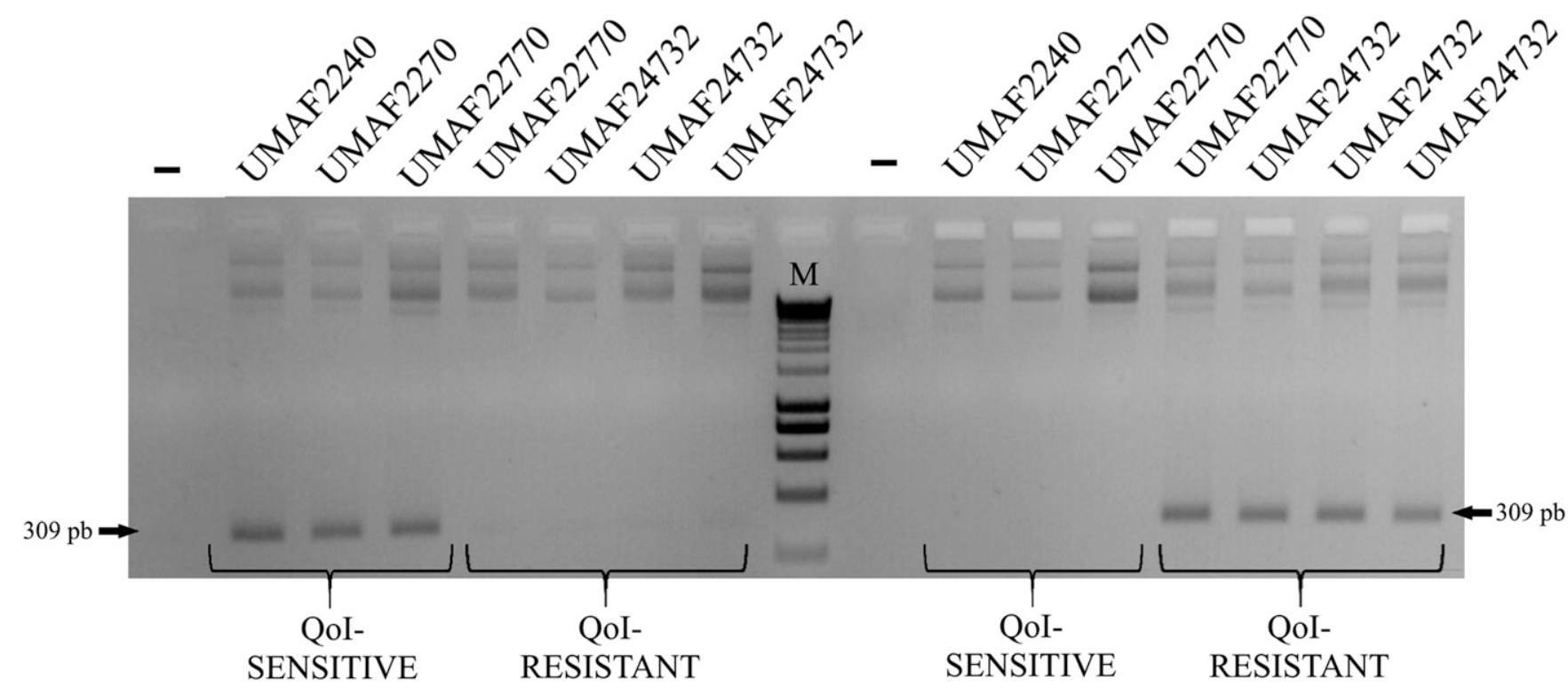

Fig. 1. ARMS PCR of the cytb G143A alleles for Podosphaera xanthii clones 10, 4, and 5 (G143 Qol-sensitive allele) of the isolates UMAF2240 and UMAF22770; and clones 10, 5 , 7, and 8 (A143 Qol-resistant allele) of the isolates UMAF22770 and UMAF24732. Lanes 1-8, Qol-sensitive alleles were amplified with the F3cytb-Px/ARMS-cytbS primer combination; lanes 10-17, resistant alleles were specifically amplified with primer combination F3cytb-Px/ARMS-cytbR. Lanes 1 and 10, non-template controls; line 9 , Hyperladder $1 \mathrm{~kb}$ (M; Bioline). 
with seven kresoxim-methyl concentrations (Fernández-Ortuño et al. 2006). The 10 QoI-sensitive isolates showed $\mathrm{EC}_{50}$ values ranging from 0.6 to $8 \mu \mathrm{g} / \mathrm{ml}$ (Table 1). The 12 QoI-resistant isolates showed, in all cases, $\mathrm{EC}_{50}$ values estimated as $>500 \mu \mathrm{g} / \mathrm{ml}$ (Table 1).

Mutations in the risp and cytb genes. Because amino acid changes in the Qo pocket of the mitochondrial cytochrome $b c_{1}$ complex have been associated with QoI resistance, the presence of mutations in risp and cytb was investigated. A PCR product of approximately $1.0 \mathrm{~kb}$ of the risp gene was amplified in six isolates, three QoI-sensitive and three QoI-resistant. This fragment encoded for a 232 amino acid protein and had four introns with sizes of 52, 65,70 , and $127 \mathrm{bp}$ (data not shown). No point mutations were detected in the risp gene of the QoI-resistant isolates showed the same nucleotide sequence as the sensitive ones (data not shown). All sequences were deposited at the National Center for Biotechnology Information (NCBI) under GenBank accession numbers MG699444 to MG69949.

The presence of mutations in $c y t b$ was also investigated in 10 QoIsensitive and 12 QoI-resistant isolates. In all cases, a single PCR product of $323 \mathrm{bp}$ was obtained and subsequently sequenced. No intron was observed in any of the $c y t b$ fragments amplified (data not shown). Sequencing analysis revealed nucleotide substitutions that corresponded with amino acid changes at positions 135, 136, and 143. Substitutions at amino acid positions 135 and 136, which have not been associated with QoI resistance previously, did not correlate with a resistant phenotype (data not shown). A substitution of glycine (GGT) with alanine (GCT) at position 143, which is responsible for QoI resistance in numerous fungal pathogens, was consistently observed in QoI-resistant isolates; however, this amino acid substitution was also observed in sensitive isolates (Table 1). The monoconidial isolates of $P$. xanthii appeared to carry both the mutated $c y t b$ gene and the wild-type allele as also shown in electropherograms with overlapping guanine $(\mathrm{G})$ and cytosine $(\mathrm{C})$ peaks at position 143 (data not shown). To show that the overlapping peaks of the sequencing reactions are the result of a mitochondrial heteroplasmic state, $c y t b$ fragments from the 22 isolates of $P$. xanthii were cloned and sequenced. Sequencing of multiple cloned $c y t b$ fragments demonstrated the occurrence of mitochondrial heteroplasmy for all isolates (Table 2). The frequency of mutated alleles ranged from 10 to $60 \%$ in QoIsensitive isolates, and from 70 to $100 \%$ in the resistant ones (Table 2).

Quantification of G143 and A143 cytb alleles by ARMS qPCR. Before unknown samples were evaluated using the ARMS qPCR, the primers were validated. The mismatched allele-specific primers were able to successfully discriminate between QoI-sensitive and resistant alleles targeting DNA from different clones by PCR (Fig. 1). Then, for qPCR, the calibration steps included standard curves made by diluting wild-type or mutant plasmid DNA ranging from $1 \times 10^{-1}$ and $1 \times 10^{-5} \mathrm{ng}$. The amount of input target plasmid was linearly correlated with the threshold cycle $(\mathrm{Ct})$ values, and on the other hand, establishing heteroplasmic mixtures of known amounts of the wildtype and mutant alleles (ratios: 100/0, 70/30, 60/40, 40/60, 10/90, and 0/100), and calculating the level of heteroplasmy. Then, total DNA of 14 isolates (seven QoI-sensitive and seven QoI-resistant) were analyzed in ARMS qPCR assay using the primer sets F3cytb-Px/ARMS-cytbS and F3cytb-Px/ARMS-cytbR for detection of the G143 and A143 alleles, respectively. The QoIsensitive isolates analyzed presented $\mathrm{EC}_{50}$ values from 0.6 to 3.0 $\mu \mathrm{g} / \mathrm{ml}$ when all QoI-resistant isolates had $\mathrm{EC}_{50}$ values $>500 \mu \mathrm{g} / \mathrm{ml}$ (Table 1; Fig. 2). In QoI-resistant isolates UMAF3180, UMAF3190, UMAF31443, UMAF 31464, UMAF31846, UMAF61140, and UMAF72174, the frequency of the A143 allele was 80, 89, 75, 76, 85,87 , and $71 \%$, respectively, with an average of $80.3 \%$ (Fig. 2). Accordingly, in these isolates, the frequency of the G143 allele ranged from 11 to $29 \%$, with an average of $19.7 \%$. The overall frequencies of the A143 and G143 alleles in the QoI-sensitive isolates (UMAFSf8, UMAFSf61, UMAF2201, UMAF2240, UMAF2208, UMAF24732, and UMAF81960) were 57.4 and $42.6 \%$, respectively (Fig. 2). No relation between $\mathrm{EC}_{50}$ values and amount of A143 allele was found in sensitive isolates. For example, isolates UMAF2240 and UMAF2201 with $\mathrm{EC}_{50}$ values of 0.7 and $3.0 \mu \mathrm{g} / \mathrm{ml}$, respectively, presented similar frequencies of mutant and wild-type alleles.

\section{Discussion}

Contrary to previous observations (Fernández-Ortuño et al. 2008b), QoI resistance in $P$. xanthii populations was found to be associated with the amino acid substitution G143A. A collection of 22 isolates characterized in previous studies (Fernández-Ortuño et al. 2006, 2008b) was subjected to genotypic studies by sequencing a partial fragment of the $c y t b$ gene containing codon position 143 . The $P$. xanthii cytb sequences were slightly different from those previously obtained using multiple displacement amplification (MDA) (Fernández-Ortuño et al. 2007, 2008b). Cytb sequences in the current study revealed G143A substitutions in all Spanish isolates of $P$. xanthii with high levels of resistance. These differences could likely be due to the MDA methodology itself (Fernández-Ortuño et al. 2007), which may amplify the sensitive $c y t b$ allele more efficiently than the resistant ones. Although MDA provides fairly even coverage over the whole genome (Dean et al. 2002; Fernández-Ortuño et al. 2007; Zhang et al. 2015), one of the most important limitations of this technique is the allelic dropout (ADO) phenomenon (Lauri et al. 2013; Ren et al. 2007; Spits et al. 2006; Treff et al. 2011). ADO results from the preferential amplification of one of a pair of heterozygous alleles, in which the other allele is under-represented. It has

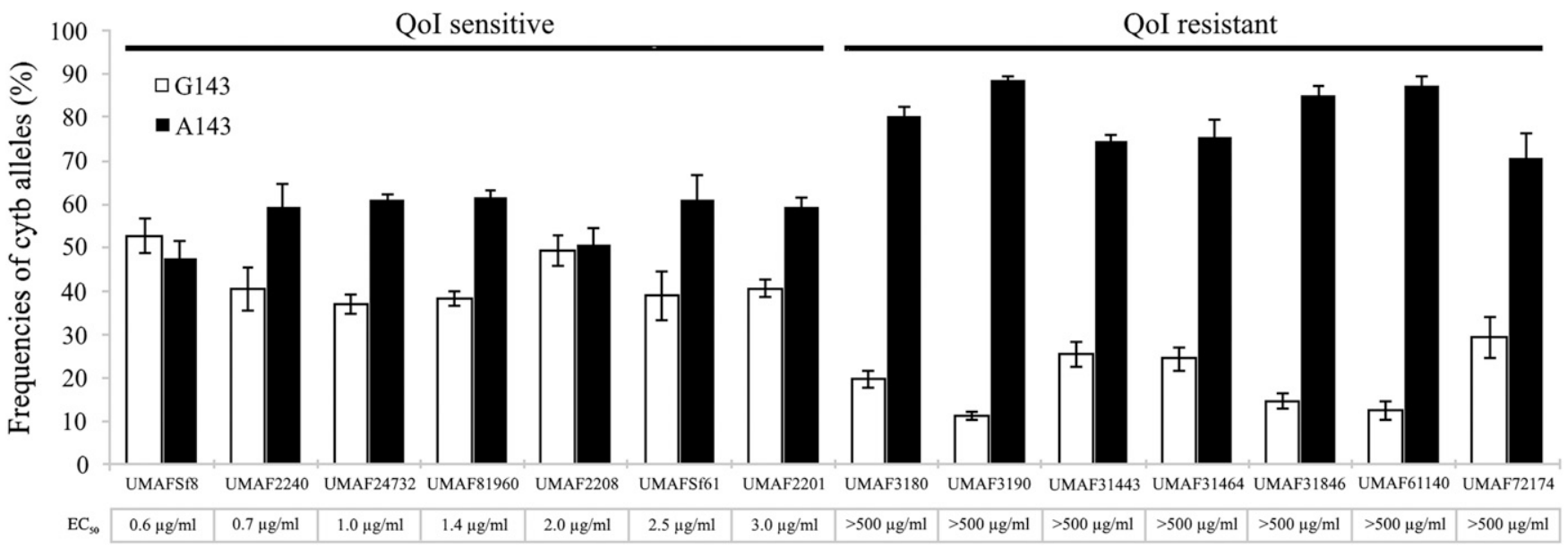

Fig. 2. Frequencies of sensitive G143 and resistant A143 cytb alleles in Qol-sensitive and Qol-resistant isolates of Podosphaera xanthii. Relative abundance of cytb alleles was calculated by qPCR as shown in Materials and Methods. Mean values and standard deviations were calculated from at least three biological replicates. 
been previously demonstrated that $\mathrm{ADO}$ can occur in alleles differing by a single nucleotide, where either the normal or the mutant genotype is absent, and it is not overcome by primer extension preamplification or increasing the amount of DNA template (Hahn et al. 1998).

Cytochrome $b$ is encoded by the mitochondrial genome (Zheng and Köller 1997); as a consequence, resistance to QoIs is expected to be inherited in a non-Mendelian way (Ziogas et al. 2002). Mitochondrial DNA exists in large copy numbers per cell and, as result of unequal inheritance of mitochondria between germ cells, alleles of these genes can coexist disproportionally. With respect to the amino acid change G143A in Cytb, some reports have described mitochondrial heteroplasmy in different powdery mildew species and other fungal pathogens (Fraaije et al. 2002; Hashimoto et al. 2015; Lesemann et al. 2006; Villani and Cox 2014). The term heteroplasmy is used to describe the simultaneous presence within an individual cell of mitochondria carrying QoI-sensitive alleles and mitochondria carrying QoI-resistant alleles. The proportion of each allele may determine the level of QoI resistance (Wei et al. 2009). In our study, heteroplasmy for the $P$. xanthii cytb gene was determined by sequencing and by qPCR. Our findings support the hypothesis that resistant and sensitive mitochondria are frequently in the heteroplasmic state. Our study showed that a mutated allele frequency of more than $70 \%$ is necessary to confer a QoI-resistant phenotype. Other authors have described similar frequencies of mutated cytb alleles associated with QoI resistance. Thus, field isolates of $V$. inaequalis with high levels of in vitro resistance to QoI fungicides showed A143 alleles frequencies of more than $62 \%$ (Villani and Cox 2014) or from 50 to $100 \%$ (Michalecka et al. 2011).

Heteroplasmy for $c y t b$ and other mitochondrial genes has also been linked to distinct phenotypes in other organisms. For example, resistance to the insecticide bifenazate in an arthropod pest (Tetranychus urticae) has been correlated with mutations in cytb at a frequency of $60 \%$ or more (Van Leeuwen et al. 2008). In medical sciences, the threshold level varies for each mutation and tissue, but typically, a range of 60 to $90 \%$ mutant mtDNA is necessary before biochemical defects and tissue dysfunction become apparent (Tuppen et al. 2010). Regarding $c y t b$ mutations, the amino acid substitution G339E, which was identified as the primary cause of a patient with myopathy, was found to be $85 \%$ heteroplasmic in muscle (Andreu et al. 1999). Similarly, the mutation Y278C, which has been associated with multisystem manifestations, was found to be heteroplasmic in muscle (88\%) and leukocytes (15\%) (Wibrand et al. 2001).

The A143 mutation could exist homoplasmically in QoI-resistant isolates in the presence of fungicide and then gradually revert to heteroplasmic status in the absence of selection pressure. This could be another reason why G143A was not detected in our previous study (Fernández-Ortuño et al. 2008b). In that work, analyzed $P$. xanthii isolates were grown for several generations without fungicidal pressure to obtain enough fungal biomass for several studies (FernándezOrtuño et al. 2006; López-Ruiz et al. 2010). Thus, the absence of fungicidal selection pressure together with the allelic dropout limitation of the MDA technique could have decreased the proportion of mutated mtDNA, and prevented the detection of the A143 allele (Fernández-Ortuño et al. 2008b).

Contradictory results have been published in other powdery mildews including $P$. xanthii. Ishii et al. (2007) demonstrated that after $3 \frac{1}{2}$ years of subculturing on untreated cucumber leaves, QoIresistant $P$. xanthii isolates were able to maintain high azoxystrobin resistance, although sequencing of the $c y t b$ gene showed reversion of the mutated allele to the wild-type at position 143 (Ishii et al. 2007). Unfortunately, the authors did not determine the G143/A143 allele frequency. In the wheat powdery mildew B. graminis $\mathrm{f}$. sp. tritici, most isolates tested were found to be nearly homoplasmic for either the A143 or G143 allele in qPCR quantifications; however, a mixed population of alleles was detected in some monosporic isolates. In these isolates, QoI resistance was not always stable when they were maintained for many generations in the absence of selection pressure (Fraaije et al. 2002). By contrast, QoI-resistant isolates of Erysiphe necator harboring high proportions of G143A (almost 100\%) were found to retain their resistant phenotype after 50 consecutive transfers on fungicide-free grape leaves (Rallos et al. 2014). Similar resistance stability was also observed in Alternaria alternata (Vega and Dewdney 2014), Cercospora beticola (Malandrakis et al. 2006), and Magnaporthe grisea (Ávila-Adame and Köller 2003). Contradictory results about resistance stability have been described in $B$. cinerea (Kim and Xiao 2011; Markoglou et al. 2006) and V. inaequalis (Frederick et al. 2014; Zheng et al. 2000).

Regarding fitness costs associated with the G143A mutation, different results have been described in several fungal species. Mutations associated with fungicide resistance may display deleterious pleiotropic effects, known as fitness cost, that become apparent in the absence of fungicide selection pressure (Jeger et al. 2008). Evolution of fungicide resistance in fungal populations is dependent on the fitness of isolates that affects the dynamics of competition between resistant and sensitive isolates, and this has important implications for disease management (Parnell et al. 2005). The evolution of fungicide resistance would be lessened if resistant subpopulations had lower parasitic or saprophytic fitness. In contrast, absence of fitness cost in the resistant fraction of the population would lead to stable resistance frequency in the absence of fungicide pressure or to rapid development and evolution of resistance in the presence of fungicide pressure (Karaoglanidis et al. 2011). The lack of significant fitness penalty associated with QoI resistance has been confirmed by measuring several biological, epidemiological parameters and estimating the competitive ability between QoI-resistant and -sensitive isolates of A. alternata (Karaoglanidis et al. 2011), B. cinerea (Banno et al. 2009; Veloukas et al. 2014), Cercospora sojina (Zhang and Bradley 2017), E. graminis f. sp. tritici (Chin et al. 2001), E. necator (Rallos et al. 2014), M. grisea (Ávila-Adame and Köller 2003), Penicillium digitatum (Zhang et al. 2009), and Plasmopara viticola (Corio-Costet et al. 2011). However, other reports have suggested decreased fitness and competitive ability in P. viticola (Genet et al. 2006) and M. oryzae (Ma and Uddin 2009) QoI-resistant isolates.

In conclusion, the results of this study demonstrate the important role of heteroplasmy for the $c y t b$ gene in the high levels of resistance to QoI fungicides in P. xanthii. In addition, an ARMS qPCR assay was successfully developed to quantify the frequency of the G143 and A143 cytb alleles in this fungus. Allele-specific qPCR techniques have allowed the rapid detection of genotypes associated with QoI resistance in other fungi such as B. graminis (Fraaije et al. 2002), Fusicladium carpophilum (Luo et al. 2013), and V. inaequalis (Villani and Cox 2014). Our results suggest that our allele-specific qPCR assay could be useful for monitoring QoI resistance in $P$. xanthii populations in cucurbit crops, thus helping to achieve more efficient control of cucurbit powdery mildew disease through more effective management of QoI resistance.

\section{Acknowledgments}

D. Bellón-Gómez was supported by a Ph.D. fellowship from the FPI program of MICINN.

\section{Literature Cited}

Álvarez, B., and Torés, J. A. 1997. Cultivo in vitro de Sphaerotheca fuliginea (Schlecht. ex. Fr.), efecto de diferentes fuentes de carbono sobre su desarrollo. Bol. Sanid. Veg., Plagas 23:283-288.

Andreu, A. L., Bruno, C., Dunne, T. C., Tanji, K., Shanske, S., Sue, C. M., Krishna, S., Hadjigeorgiou, G. M., Shtilbans, A., Bonilla, E., and DiMauro, S. 1999. A nonsense mutation (G15059A) in the cytochrome b gene in a patient with exercise intolerance and myoglobinuria. Ann. Neurol. 45:127-130.

Anke, T. 1995. The antifungal strobilurins and their possible ecological role. Can J. Bot. 73(S1):940-945.

Anonymous. 1998. Strobilurin-resistant mildew found in Germany. AGROW 318:11.

Ávila-Adame, C., and Köller, W. 2003. Characterization of spontaneous mutants of Magnaporthe grisea expressing stable resistance to the Qo-in- hibiting fungicide azoxystrobin. Curr. Genet. 42:332-338.

Bai, R.-K., and Wong, L.-J. 2004. Detection and quantification of heteroplasmic mutant mitochondrial DNA by real-time amplification refractory mutation system quantitative PCR analysis: A single-step approach. Clin. Chem. 50: 996-1001.

Banno, S., Yamashita, K., Fukumori, F., Okada, K., Uekusa, H., Takagaki, M., Kimura, M., and Fujimura, M. 2009. Characterization of QoI resistance in Botrytis cinerea and identification of two types of mitochondrial cytochrome $b$ gene. Plant Pathol. 58:120-129. 
Bartlett, D. W., Clough, J. M., Godwin, J. R., Hall, A. A., Hamer, M., and ParrDobrzanski, B. 2002. The strobilurins fungicides. Pest Manag. Sci. 58:649-662.

Bellón-Gómez, D., Vela-Corcía, D., Pérez-García, A., and Torés, J. A. 2015. Sensitivity of Podosphaera xanthii populations to anti-powdery-mildew fungicides in Spain. Pest Manag. Sci. 71:1407-1413.

Brand, U., Haase, U., Schägger, H., and von Jagow, G. 1993. Speziesspezifität und wirkmechanismus der strobilurine. Pages 27-39 in: Wege zu neuen Produkten und Verfahren der Biotechnologié. Verlag Chemie, Weinheim, Germany.

Chin, K. M., Chavaillaz, D., Kaesbohrer, M., Staub, T., and Felsenstein, F. G. 2001. Characterizing resistance risk of Erysiphe graminis f. sp. tritici to strobilurins. Crop Prot. 20:87-96.

Corio-Costet, M.-F., Dufour, M.-C., Cigna, J., Abadie, P., and Chen W.-J. 2011. Diversity and fitness of Plasmopara viticola isolates resistant to QoI fungicides. Eur. J. Plant Pathol. 129:315-329.

Dean, F. B., Hosono, S., Fang, L., Wu, X., Faruqi, A. F., Bray-Ward, P., Sun, Z., Zong, Q., Du, Y., Du, J., Driscoll, M., Song, W., Kingsmore, S. F., Egholm, M., and Lasken, R. S. 2002. Comprehensive human genome amplification using multiple displacement amplification. Proc. Natl. Acad. Sci. USA 99: 5261-5266.

Fernández-Ortuño, D., Pérez-García, A., López-Ruiz, F. J., Romero, D., de Vicente, A., and Torés, J. A. 2006. Occurrence and distribution of resistance to QoI fungicides in populations of Podosphaera fusca in south central Spain. Eur. J. Plant Pathol. 115:215-222.

Fernández-Ortuño, D., Torés, J. A., de Vicente, A., and Pérez-García, A. 2007. Multiple displacement amplification, a powerful tool for molecular genetic analysis of powdery fungi. Curr. Genet. 51:209-219.

Fernández-Ortuño, D., Torés, J. A., de Vicente, A., and Pérez-García, A. 2008a. Mechanisms of resistance to QoI fungicides in phytopathogenic fungi. Int. Microbiol. 11:1-9.

Fernández-Ortuño, D., Torés, J. A., de Vicente, A., and Pérez-García, A. 2008b. Field resistance to QoI fungicides in Podosphaera fusca is not supported by typical mutations in the mitochondrial cytochrome $b$ gene. Pest Manag. Sci. 64:694-702.

Fraaije, B. A., Butters, J. A., Coelho, J. M., Johes, D. R., and Hollomon, D. W. 2002. Following the dynamics of strobilurin resistance in Blumeria graminis f. sp. tritici using quantitative allele-specific real time PCR measurements with the fluorescent dye SYBR green I. Plant Pathol. 51:45-54.

Frederick, Z. A., Villani, S. M., Cooley, D. R., Biggs, A. R., Raes, J. J., and Cox, K. D. 2014. Prevalence and stability of qualitative QoI resistance in populations of Venturia inaequalis in the northeastern United States. Plant Dis. 98:1122-1130.

Genet, J.-L., Jaworska, T. G., and Deparis, F. 2006. Effect of dose rate and mixtures of fungicides on selection for QoI resistance in populations of Plasmopara viticola. Pest Manag. Sci. 62:188-194.

Gisi, U., Sierotzki, H., Cook, A., and McCaffery, A. 2002. Mechanisms influencing the evolution of resistance to Qo inhibitor fungicides. Pest Manag. Sci. 58: 859-867.

Hahn, S., Garvin, A. M., Di Naro, E., and Holzgreve, W. 1998. Allele drop-out can occur in alleles differing by a single nucleotide and is not alleviated by preamplification or minor template increments. Genet. Test. 2:351-355.

Hashimoto, M., Aoki, Y., Saito, S., and Suzuki, S. 2015. Characterisation of heteroplasmic status at codon 143 of the Botrytis cinerea cytochrome $\mathrm{b}$ gene in a semi-quantitative AS-PCR assay. Pest Manag. Sci. 71:467-477.

Ishii, H., Fraaije, B. A., Sugiyama, T., Noguchi, K., Nishimura, K., Takeda, T., Amano, T., and Hollomon, D. W. 2001. Occurrence and molecular characterization of strobilurin resistance in cucumber powdery mildew and downy mildew. Phytopathology 91:1166-1171.

Ishii, H., Yano, K., Date, H., Furuta, A., Sagehashi, Y., Yamaguchi, T., Sugiyama, T., Nishimura, K., and Hasama, W. 2007. Molecular characterization and diagnosis of QoI resistance in cucumber and eggplant fungal pathogens. Phytopathology 97:1458-1466

Jeger, M. J., Wijngaarden, P. J., and Hoekstra, R. F. 2008. Adaptation to the cost of resistance in a haploid clonally reproducing organism: the role of mutation, migration and selection. J. Theor. Biol. 252:621-632.

Karaoglanidis, G. S., Luo, Y., and Michailides, T. J. 2011. Competitive ability and fitness of Alternaria alternate isolates resistant to QoI fungicides. Plant Dis. 95: 178-182.

Kearse, M., Moir, R., Wilson, A., Stones-Havas, S., Cheung, M., Sturrock, S., Buxton, S., Cooper, A., Markowitz, S., Duran, C., Thierer, T., Ashton, B., Mentjies, P., and Drummond, A. 2012. Geneious Basic: an integrated and extendable desktop software platform for the organization and analysis of sequence data. Bioinformatics 28:1647-1649.

Kim, Y. K., and Xiao, C. L. 2011. Stability and fitness of pyraclostrobin- and boscalid-resistant phenotypes in field isolates of Botrytis cinerea from apple. Phytopathology 101:1385-1391.

Lauri, A., Lazzari, G., Galli, C., Lagutina, I., Genzini, E., Braga, F., Mariani, P., and Williams, J. L. 2013. Assessment of MDA efficiency for genotyping using cloned embryo biopsies. Genomics 101:24-29.

Lesemann, S. S., Schimpke, S., Dunemann, F., and Deising, H. B. 2006. Mitochondrial heteroplasmy for the cytochrome $b$ gene controls the level of strobilurin resistance in the apple powdery mildew fungus Podosphaera leucotricha (Ell. \& Ev.). E.S. Salmon. J. Plant Dis. Prot. 113:259-266.

López-Ruiz, F. J., Pérez-García, A., Fernández-Ortuño, D., Romero, D., García, E., Cánovas, I., de Vicente, A., Brown, J. K. M., and Torés, J. A. 2010.
Sensitivity to DMI fungicides in populations of Podosphaera fusca in south central Spain. Pest Manag. Sci. 66:801-808

Luo, Y., Hou, L., Förster, H., and Adaskaveg, J. E. 2013. QoI resistance in Fusicladium carpophilum populations from almond in California and evaluation of molecular resistance mechanisms. Plant Dis. 97:1322-1330.

Ma, B., and Uddin, W. 2009. Fitness and competitive ability of an axoxystrobinresistant G143A mutant of Magnaporthe oryzae from perennial ryegrass. Plant Dis. 93:1044-1049

Malandrakis, A., Markoglou, A., Nikou, D., Vontas, J., and Ziogas, B. 2006 Biological and molecular characterization of laboratory mutants of Cercospora beticola resistant to Qo inhibitors. Eur. J. Plant Pathol. 116:155-166.

Markoglou, A., Malandrakis, A. A., Vitoratos, A. G., and Ziogas, B. N. 2006 Characterization of laboratory mutants of Botrytis cinerea resistant to QoI fungicides. Eur. J. Plant Pathol. 115:149-162.

McGrath, M. T. 2001. Fungicide resistance in cucurbit powdery mildew: Experiences and challenges. Plant Dis. 85:236-245.

Michalecka, M., Malinowski, T., Broniarek-Niemiec, A., and Bielenin, A. 2011. Real-time PCR assay with SNP-specific primers for the detection of a G143A mutation level in Venturia inaequalis field populations. J. Phytopathol. 159: 569-578.

Parnell, S., Gilligan, C. A., and Van den Bosch, F. 2005. Small-scale fungicide spray heterogeneity and the coexistence of resistant and sensitive pathogen strains. Phytopathology 95:632-639.

Pérez-García, A., Mingorance, E., Rivera, M. E., del Pino, D., Romero, D., Torés, J. A., and de Vicente, A. 2006. Long-term preservation of Podosphaera xanthi using silica gel. J. Phytopathol. 154:190-192.

Pérez-García, A., Romero, D., Fernández-Ortuño, D., López-Ruiz, F. J., de Vicente, A., and Torés, J. A. 2009. The powdery mildew fungus Podosphaera fusca (synonym Podosphaera xanthii), a constant threat to cucurbit. Mol. Plant Pathol. 10:153-160.

Rallos, L. E. E., Johnson, N. G., Schmale, D. G., III, Prussin, A. J., II, and Baudoin, A. B. 2014. Fitness of Erysiphe necator with G143A-based resistance to quinone outside inhibitors. Plant Dis. 98:1494-1502.

Ren, Z., Zhou, C., Xu, Y., Deng, J., Zeng, H., and Zeng, Y. 2007. Mutation and haplotype analysis for Duchenne muscular dystrophy by single cell multiple displacement amplification. Mol. Hum. Reprod. 13:431-436.

Sedláková, B., and Lebeda, A. 2008. Fungicide resistance in Czech populations of cucurbit powdery mildews. Phytoparasitica 36:272-289.

Sierotzki, H., Parisi, S., Steinfeld, U., Tenzer, I., Poirey, S., and Gisi, U. 2000. Mode of resistance to respiration inhibitors at the cytochrome $b c_{1}$ enzyme complex of Mycosphaerella fijiensis field isolates. Pest Manag. Sci. 56:833-841.

Spits, C., le Caignec, C., de Rycke, M., van Haute, L., van Steirteghem, A., Liebaers, I., and Sermon, K. 2006. Optimization and evaluation of singlecell whole-genome multiple displacement amplification. Hum. Mutat. 27: 496-503.

Treff, N. R., Su, J., Tao, X., Northrop, L. E., and Scott, R. T., Jr. 2011. Single-cell wholegenome amplification technique impacts the accuracy of SNP microarraybased genotyping and copy number analyses. Mol. Hum. Reprod. 17:335-343

Tuppen, H. A. L., Blakely, E. L., Turnbull, D. M., and Taylor, R. W. 2010 Mitochondrial DNA mutations and human disease.Biochim. Biophys. Acta 1797:113-128.

Van Leeuwen, T., Vanholme, B., Van Pottelberge, S., Van Nieuwenhuyse, P., Nauen, R., Tirry, L., and Denholm, I. 2008. Mitochondrial heteroplasmy and the evolution of insecticide resistance: non-Mendelian inheritance in action. Proc. Natl. Acad. Sci. USA 105:5980-5985

Vega, B., and Dewdney, M. M. 2014. QoI-resistance stability in relation to pathogenic and saprophytic fitness components of Alternaria alternata from citrus. Plant Dis. 98:1371-1378.

Veloukas, T., Kalogeropoulou, P., Markoglou, A. N., and Karaoglanidis, G. S. 2014. Fitness and competitive ability of Botrytis cinerea field isolates with dual resistance to SDHI and QoI fungicides, associated with several sdhB and the cytb G143A mutations. Phytopathology 104:347-356.

Villani, S. M., and Cox, K. D. 2014. Heteroplasmy of the cytochrome $b$ gene in Venturia inaequalis and its involvement in quantitative and practical resistance to trifloxistrobin. Phytopathology 104:945-953.

Walker, A.-S., Auclair, C., Gredt, M., and Leroux, P. 2009. First occurrence of resistance to strobilurin fungicides in Microdochium nivale and Microdochium majus from French naturally infected wheat grains. Pest Manag. Sci. 65:906-915.

Wang, J., Venegas, V., Fangyuan, L., and Wong, L.-J. 2011. Analysis of mitochondrial DNA point mutation heteroplasmy by ARMS quantitative PCR. Curr. Protoc. Hum. Genet. 68:19.6.1-19.6.16.

Wei, C. Z., Katoh, H., Nishimura, K., and Ishii, H. 2009. Site-directed mutagenesis of the cytochrome $b$ gene and development of diagnostic methods for identifying QoI resistance of rice blast fungus. Pest Manag. Sci. 65: 1344-1351.

Wibrand, F., Ravn, K., Schwartz, M., Rosenberg, T., Horn, N., and Vissing, J. 2001. Multisystem disorder associated with a missense mutation in the mitochondrial cytochrome b gene. Ann. Neurol. 50:540-543.

Xiao, Y. M., Esser, L., Zhou, F., Li, C., Zhou, Y. H., Yu, C. A., Qin, Z. H., and $\mathrm{Xia}, \mathrm{D} .2014$. Studies on inhibition of respiratory cytochrome $b c_{1}$ complex by the fungicide pyrimorph suggest a novel inhibitory mechanism. PLoS One 9 e93765. 
Zhang, G., and Bradley, C. A. 2017. Comparison of quinone outside inhibitor fungicide-resistant and -sensitive isolates of Cercospora sojina. Crop Prot. 94:59-63.

Zhang, R., Ma, Z. H., and Wu, B. M. 2015. Multiple displacement amplification of whole genomic DNA from urediospores of Puccinia striiformis f. sp. tritici. Curr. Genet. 61:221-230.

Zhang, Z., Zhu, Z., Ma, Z., and Li, H. 2009. A molecular mechanism of azoxystrobin resistance in Penicillium digitatum UV mutants and a PCRbased assay for detection of azoxystrobin-resistant strains in packing- or store-house isolates. Int. J. Food Microbiol. 131:157-161.
Zheng, D. S., and Köller, W. 1997. Characterization of the mitochondrial cytochrome $b$ gene from Venturia inaequalis. Curr. Genet. 32: 361-366.

Zheng, D. S., Olaya, G., and Köller, W. 2000. Characterization of laboratory mutants of Venturia inaequalis resistant to the strobilurin-related fungicide kresoxim-methyl. Curr. Genet. 38:148-155.

Ziogas, B. N., Markoglou, A. N., and Tzima, A. 2002. A non-Mendelian inheritance of resistance to strobilurin fungicides in Ustilago maydis. Pest Manag. Sci. 58:908-916. 